ISSN 1392-3196 / e-ISSN 2335-8947

Zemdirbyste-Agriculture, vol. 107, No. 3 (2020), p. 249-254

DOI $10.13080 / \mathrm{z}-\mathrm{a} .2020 .107 .032$

\title{
Increase in resistance to sulfonylurea herbicides in Alopecurus myosuroides populations in north-eastern Poland
}

\author{
Marta STANKIEWICZ-KOSYL, Mariola WROCHNA, Mateusz TOŁŁOCZKO \\ Warsaw University of Life Sciences - SGGW, Faculty of Horticulture and Biotechnology \\ Nowoursynowska 159, 02-776 Warsaw, Poland \\ E-mail: marta_stankiewicz_kosyl@sggw.pl
}

\begin{abstract}
The number of herbicide-resistant populations of black-grass (Alopecurus myosuroides Huds.) in winter cereal crops in Europe is increasing, leading to serious restrictions in winter cereal production. The aim of this study was to evaluate the reaction of five $A$. myosuroides populations: four suspected as being herbicide-resistant and one susceptible to mesosulfuron + iodosulfuron-based herbicide (acetolactate synthase (ALS) inhibitor). Mutation events in domains A and B of the als gene, and the relationship between resistance to mesosulfuron + iodosulfuron and plant fitness in the early vegetative stage were also examined. The fitness was assessed on the basis of tillering, average leaf number, dry mass accumulation, chlorophyll content and photosystem II efficiency.

The whole-plant bioassay confirmed resistance to ALS inhibitors in four A. myosuroides populations, and the level of reduction of biomass accumulation after herbicide treatment corresponded with the number of als gene mutations conferring resistance in the population. Non-treated populations did not differ significantly in biomass accumulation, chlorophyll content or photosystem II efficiency. However, particular ALS-resistant populations revealed more intensive tillering than the susceptible population. In the examined A. myosuroides populations, resistance conferring mutations (Pro197Thr and Trp574Leu) of the als gene were identified. These mutations have not been found in Poland before. In two populations there were some survivors after mesosulfuron + iodosulfuron treatment, where no mutation in the als gene was identified. The survival rate in these populations after herbicide treatment suggests that these populations were composed of individuals with target-site resistance (TSR) and nontarget-site resistance (NTSR) to mesosulfuron + iodosulfuron.
\end{abstract}

Key words: ALS inhibitors, black-grass, mesosulfuron + iodosulfuron, plant fitness, target-site resistance.

\section{Introduction}

Weed competition in crops is a serious problem in agriculture (Yu, Powles, 2014 a; Auškalnienè et al., 2018; Velička et al., 2018). In recent years, the eradication of weeds in crops has mostly been based on herbicides targeting particular metabolic pathways, e.g., acetolactate synthase (ALS, also referred to as acetohydroxyacid synthase, AHAS), acetyl-coenzyme A carboxylase (ACCase) and D1 protein within photosystem II, etc. (Powles, Yu, 2010). Due to high selectivity in major world crops, herbicides inhibiting ALS have recently attracted considerable interest. They stop the synthesis of branched-chain amino acids, leading to plant death. They are able to control many weed species, while exhibiting low mammalian toxicity (Yu, Powles, 2014 b).

Since selective herbicides have been applied, weed populations have developed several resistance mechanisms, grouped as target-site resistance (TSR) and non-target-site resistance (NTSR). TSR is caused by a mutation within a gene coding for an herbicide target-site enzyme (limiting herbicide binding) or by overproduction of the target enzyme. In the case of ALS resistant weeds with TSR, mechanism mutations have been identified in triplets coding for amino acids in eight positions on the
ALS enzyme: Ala122, Pro197, Ala205, Asp376, Arg377, Trp574, Ser653 and Gly654 (Heap, 2019). NTSR encompasses mechanisms that decrease the amount of active herbicide influencing the target site (Yu, Powles, $2014 \mathrm{a} ; \mathrm{b}$ ). In many cases, combined TSR and NTSR has been observed. This has also been found as a reaction to ALS-inhibiting herbicides based on mesosulfuron and iodosulfuron (Hull et al., 2014).

Fitness, or success in the field, can be defined as the ability to establish, survive and reproduce successfully in a given environment. Fitness alterations can be exploited to predict population dynamics and establish resistance management strategies (Darmency et al., 2014). Mutations conferring resistance to pesticides are generally expected to generate a fitness cost in the absence of this selection pressure (Vila-Aiub et al., 2009). However, increased fitness of herbicideresistant populations has also been noted (Wang et al., 2010; Babineau et al., 2017).

Black-grass (Alopecurus myosuroides Huds.) is a weed that commonly occurs in winter cereals (Moss et al., 2011; Hull et al., 2014; Pacanoski, 2018). In Poland it is considered to be an archaeophyte that was introduced

Please use the following format when citing the article:

Stankiewicz-Kosyl M., Wrochna M., Tołłoczko M. 2020. Increase in resistance to sulfonylurea herbicides in Alopecurus myosuroides populations in north-eastern Poland. Zemdirbyste-Agriculture, 107 (3): 249-254. DOI 10.13080/z-a.2020.107.032 
in around the $15^{\text {th }}$ century (Zajac, Zajac, 2014) and was described for the first time in 1919 by Raciborski and Szafer (Trzcińska-Tacik, Stachurska-Swakoń, 2011). Its occurrence was noted mostly in Silesia and north-eastern Poland.

In recent years $A$. myosuroides has become one of the most intrusive herbicide-resistant weeds in Europe (Domaradzki et al., 2010; Hull et al., 2014). The species has high seed productivity with around 500 viable seeds produced by one plant. Although about $20 \%$ of the seeds germinate in spring, most of the seeds germinate in autumn, therefore, winter cereals are threatened more (Maréchal et al., 2012).

The timing of germination and seedling growth of $A$. myosuroides from different populations varies; therefore, the species shows great plasticity and tolerance to changing habitat conditions. Abundant A. myosuroides populations in wheat have been identified in a number of European countries, including England, France and Germany (Delye et al., 2010; Rosenhauer et al., 2013; Hull et al., 2014). Recent papers have indicated its adaptation ability to develop resistance mechanisms to a range of selective herbicides. Since the first use of mesosulfuron + iodosulfuron herbicide in the UK, by 2013 the resistance of $A$. myosuroides to mesosulfuron + iodosulfuron had been confirmed on over 700 farms in 27 counties of England (Hull et al., 2014).

The same is true in Poland. While Domaradzki and Rola (2006) discuss successful A. myosuroides eradication with mesosulfuron + iodosulfuron herbicides in the district of Opole (south-western Poland) in 2006, there were reports in 2011 of a resistant population with TSR and a mutation in the A domain of ALS (als) gen (Krysiak et al., 2011). In 2016, resistant populations were not only detected in south-western Poland but also in the north of the country, i.e. in Kmiecin $\left(54^{\circ} 11^{\prime} 18^{\prime \prime} \mathrm{N}\right.$, $\left.19^{\circ} 08^{\prime} 36^{\prime \prime} \mathrm{E}\right)$, Sułowo $\left(54^{\circ} 05^{\prime} 47^{\prime \prime} \mathrm{N}, 20^{\circ} 49^{\prime} 40^{\prime \prime} \mathrm{E}\right)$ and Łabędnik $\left(54^{\circ} 11^{\prime} 04^{\prime \prime} \mathrm{N}, 20^{\circ} 58^{\prime} 08^{\prime \prime} \mathrm{E}\right)$ (Adamczewski et al., 2016).

Unfortunately, A. myosuroides is a very plastic species, and there are populations in many countries that have evolved resistance not only to ALS inhibitors but to ACCase, photosystem II, long-chain fatty acid and lipid synthesis inhibitors as well (Heap, 2019). This multidimensional resistance impedes and decreases winter crop production and may lead to the ultimate cessation of production of winter cereals, as has been the case in some counties in England (Moss et al., 2011; Hull et al., 2014).

The objective of the present study was: (i) to evaluate the reaction of examined populations to mesosulfuron + iodosulfuron, (ii) detect mutations in domains $\mathrm{A}$ and $\mathrm{B}$ of the als gene conferring resistance to acetolactate synthase (ALS) inhibitors, and (iii) identify the relationship between resistance to mesosulfuron + iodosulfuron and tillering, average leaf number, dry mass accumulation, chlorophyll content and photosystem II efficiency. We tested the following hypotheses: (i) ALSinhibitor resistance of examined Alopecurus myosuroides populations is conditioned both by target-site resistance (TSR) and non-target-site resistance (NTSR), (ii) ALSinhibitor resistance in black-grass is increasing in Poland, and (iii) there are differences in fitness among the analysed $A$. myosuroides populations.

\section{Materials and methods}

Plant material. Four populations of black-grass (Alopecurus myosuroides Huds.) were tested. Field samples of four populations suspected to be resistant to acetolactate synthase (ALS)-inhibiting herbicides were collected in 2016 from the districts of Bartoszyce (54 $\left.14^{\prime} 56^{\prime \prime} \mathrm{N}, 20^{\circ} 48^{\prime} 29^{\prime \prime} \mathrm{E}\right)$ (RI and RII populations) and Kętrzyn $\left(54^{\circ} 04^{\prime} 37^{\prime \prime} \mathrm{N}, 2^{\circ} 22^{\prime} 31^{\prime \prime} \mathrm{E}\right.$ ) (RIII and RIV populations) in Warmian-Masurian Voivodeship, Poland. Samples were suspected to be resistant based on interviews with farmers and chemical advisors working in the crop protection supply chain. A susceptible (S) population was acquired from Błotnik in the district of Gdańsk in Pomeranian Voivodeship (54¹6'33" N, $\left.18^{\circ} 52^{\prime} 30^{\prime \prime} \mathrm{E}\right)$, Poland. Each sample contained more than 100 ears from at least 30 plants. Individuals from winter wheat fields with very poor herbicide control of A.myosuroides, despite being sprayed with full label doses, were harvested and classified for further greenhouse and laboratory tests, which were conducted in 2017.

Whole-plant resistance bioassay. Seeds of A. myosuroides were stored in a refrigerator for seven days at a temperature of approximately $-4^{\circ} \mathrm{C}$ in order to interrupt seed dormancy. The seeds were then sown into river sand and after germination moved to pots of a volume of $0.5 \mathrm{dm}^{3}$ filled with a mineral sandy-clayey soil. Five pots per sample, each containing five seedlings, were used for the experiment.

The seedlings at a stage of 2-3 leaves (two weeks after sowing) were sprayed with herbicide Atlantis $12 \mathrm{OD}$ (a.i. mesosulfuron + iodosulfuron) following the manufacturer's recommendations, i.e. single (1LD = $2.4 \mathrm{~g} \mathrm{ha}^{-1}$ of iodosulfuron $+12 \mathrm{~g} \mathrm{ha}^{-1}$ of mesosulfuron) and double $\left(2 \mathrm{LD}=4.8 \mathrm{~g} \mathrm{ha}^{-1}\right.$ of iodosulfuron $+24 \mathrm{~g} \mathrm{ha}^{-1}$ of mesosulfuron) doses. The herbicide was applied with a sprayer equipped with a single nozzle calibrated to deliver $300 \mathrm{~L} \mathrm{ha}^{-1}$ at a spraying pressure of $200 \mathrm{kPa}$. After six weeks, shoot dry mass (DM) was determined and samples for molecular analyses collected.

Analysis of selected morphological and physiological parameters. Plants for the evaluation of morphological traits and photosynthetic apparatus efficiency were prepared in the same manner as for the whole-plant bioassay. Four weeks after germination, the number of leaves and number of tillers in each plant were determined. After a further four weeks, the relative chlorophyll content was assessed using a chlorophyll content meter CCM-200 (Opti-Science, USA), chlorophyll $a$ fluorescence was measured using a fluorimeter Handy-PEA (Hansatech Instruments Ltd., UK), and the number of tillers was determined.

Molecular analysis. Molecular analysis was undertaken in order to check the presence of the targetsite resistance (TSR) mechanism of resistance to ALS (mesosulfuron + iodosulfuron) inhibitors in analysed populations of $A$. myosuroides. The DNA was extracted from three plants from each of the $1 \mathrm{LD}$ and $2 \mathrm{LD}$ treatments using the CTAB (cetyltrimethylammonium bromide) method (Doyle, Doyle, 1987). Primer sequences for amplification of domains A and B of the als gene were as described by Krysiak et al. (2011). Genomed S.A. (Poland) was commissioned to undertake purification of the PCR product and sequencing. Chromatograms were analysed using software FinchTV (Geospiza, USA). The obtained sequences were compared using the onlineaccessed software ClustalW (GenomeNet, Japan).

Statistical analysis. To compare results, a oneway analysis of variance (ANOVA) was performed using software Statgraphics Plus, version 4.1 (Statpoint Technologies Inc., USA). Differences between means of samples were evaluated by HSD (honestly significant difference) Tukey test at $\alpha=0.05$. The presented data are means \pm standard error (SE). The number of biological replications (single plant in a container) was five. 


\section{Results and discussion}

Photosynthetic apparatus efficiency, assessed as the chlorophyll content index and chlorophyll $a$ fluorescence of non-treated susceptible and resistant populations of $A$. myosuroides, did not differ significantly (Table 1).
Similar results were obtained by Kaiser et al. (2013). Six A. myosuroides populations of different herbicide susceptibility did not show significantdifferences in maximum quantum efficiency of photosystem II $\left(\mathrm{F}_{\mathrm{v}}: \mathrm{F}_{\mathrm{m}}\right)$ during seven days of measurements. Shoot dry mass accumulation in all populations was not affected significantly (Fig. 1).

Table 1. Efficiency of the photosynthetic apparatus and morphological parameters of Alopecurus myosuroides plants tested in a greenhouse pot trial

\begin{tabular}{cccccc}
\hline Population & CCI & $\mathrm{F}_{\mathrm{v}}: \mathrm{F}_{\mathrm{m}}$ & PI & $\mathrm{L}$ & Tillers \\
\hline S & & & & & $4 / 8$ weeks \\
RI & $1.39 \mathrm{a}^{*}$ & $0.821 \mathrm{a}$ & $1.93 \mathrm{a}$ & $3.48 \mathrm{c}$ & $0.44 \mathrm{a} / 4.16 \mathrm{a}$ \\
RII & $1.40 \mathrm{a}$ & $0.822 \mathrm{a}$ & $2.20 \mathrm{a}$ & $3.40 \mathrm{bc}$ & $0.52 \mathrm{a} / 4.84 \mathrm{~b}$ \\
RIII & $1.51 \mathrm{a}$ & $0.821 \mathrm{a}$ & $2.14 \mathrm{a}$ & $3.16 \mathrm{ab}$ & $0.36 \mathrm{a} / 5.24 \mathrm{~b}$ \\
RIV & $1.35 \mathrm{a}$ & $0.815 \mathrm{a}$ & $1.87 \mathrm{a}$ & $3.24 \mathrm{abc}$ & $0.52 \mathrm{a} / 4.88 \mathrm{~b}$ \\
\hline
\end{tabular}

Note. $\mathrm{S}$ - susceptible; CCI - chlorophyll content index; $\mathrm{F}_{v}: \mathrm{F}_{\mathrm{m}}$ - maximum quantum efficiency of photosystem II; PI - performance index of photosystem II; L - number of leaves per plant (measured 4 weeks after transplantation); tillers - number of tillers per plant; 4 / 8 weeks -4 and 8 weeks after transplantation; means, letters indicate homogenous groups; * - data followed by the same letter do not differ significantly.

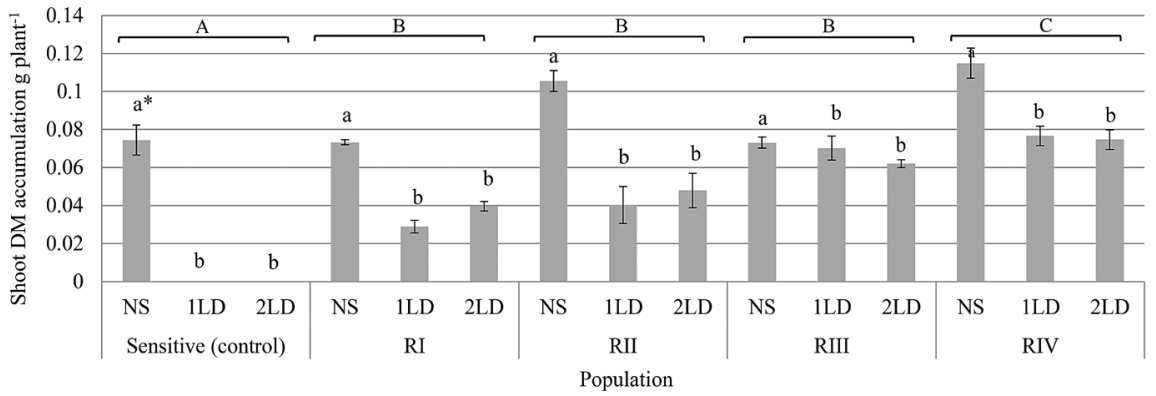

Note. Means $\pm \mathrm{SE}, \mathrm{n}=5$; $\mathrm{NS}$ - non-sprayed, $1 \mathrm{LD}-100 \%$ of the label dose $\left(2.4 \mathrm{~g} \mathrm{ha}^{-1}\right.$ of iodosulfuron $+12 \mathrm{~g} \mathrm{ha}^{-1}$ of mesosulfuron), $2 \mathrm{LD}-200 \%$ of the label dose ( $4.8 \mathrm{~g} \mathrm{ha}^{-1}$ of iodosulfuron $+24 \mathrm{~g} \mathrm{ha}^{-1}$ of mesosulfuron); ${ }^{*}$ - data followed by the same letter do not differ significantly (capital letters - population, lowercase letters - treatment).

Figure 1. Shoot dry mass (DM) accumulation in Alopecurus myosuroides seedlings treated with iodosulfuron + mesosulfuron in comparison to the non-treated seedlings of each population

Four weeks after germination, the number of leaves per plant was highest in the susceptible (S) population; RII and RIV populations revealed significantly lower leaf numbers. The highest number of tillers was noted in RIV; however, the differences were not significant (Table 1). After 8 weeks, all resistant populations showed significantly higher tiller number than the susceptible (S) population. There were no significant differences between any of the resistant populations; however, RII and RIV populations exhibited more abundant tillering on average with 5.24 in both populations. As a consequence, their shoot dry mass accumulation was higher (Fig. 1). Shoot dry mass accumulation in non-treated plants did not differ between any of the populations. Moreover, it was significantly higher than in herbicide-treated plants in each biotype.

These findings indicate that despite the developed resistance to ALS inhibitors, plants of all biotypes were affected by the mesosulfuron + iodosulfuron mixture. However, the reaction of a particular biotype depended on its resistance level. The lowest shoot dry mass decrease was noted in RIII population at $0.0029 \mathrm{~g}$ $(4 \%)$ and $0.011 \mathrm{~g}(15 \%)$ DM per plant in 1LD and 2LD treatments, respectively. The RII population showed the greatest shoot dry mass decrease (Fig. 2); however, the differences between 1LD and 2LD treatments were not significant.

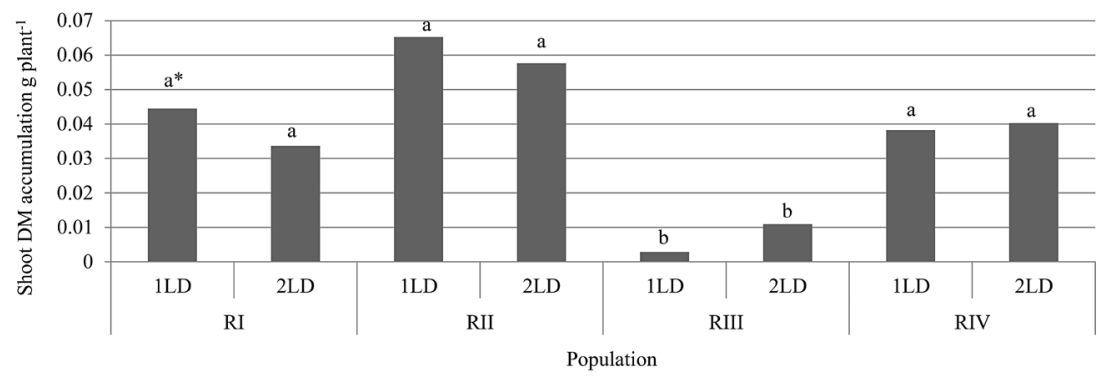

Note. $1 \mathrm{LD}-100 \%$ of the label dose $\left(2.4 \mathrm{~g} \mathrm{ha}^{-1}\right.$ of iodosulfuron $+12 \mathrm{~g} \mathrm{ha}^{-1}$ of mesosulfuron), $2 \mathrm{LD}-200 \%$ of the label dose (4.8 $\mathrm{g} \mathrm{ha}^{-1}$ of iodosulfuron $+24 \mathrm{~g} \mathrm{ha}^{-1}$ of mesosulfuron); * - data followed by the same letter do not differ significantly.

Figure 2. The decrease in shoot dry mass (DM) accumulation of herbicide-treated Alopecurus myosuroides seedlings in comparison to the non-treated seedlings of each population 
The registration procedure of herbicides determines the scale of weed susceptibility evaluation in percentage terms, taking into account population size, soil coverage, plant height and vigour, i.e. assessed weed mass (EPPO standard PP 1/181(4), 2012). Efficacy below $70 \%$ indicates intermediate susceptibility to a particular herbicide. None of the examined RI, RII, RIII and RIV populations showed shoot dry mass diminishing to such a level. Thus, irrespective of other physiological parameters, all these biotypes should be considered as being resistant to mesosulfuron + iodosulfuron. At the end of the experiment, all the examined plants were in a good condition, revealing typically green leaves and the potential to grow further without any disturbances.

In the examined $A$. myosuroides populations, mutations in one or two domains of the als gene were found (Table 2). In 2011, a mutation in domain A of the als gene was found in Poland (Krysiak et al., 2011). At position 197 of herbicide-resistant A. myosuroides, a sequence CAC instead of CCC was found, leading to the replacement of proline by histidine. In the present study, proline-encoding CCC was replaced by threonineencoding ACC. Additionally, a mutation in domain B (Trp574Leu) was found. These types of mutations have been found already in $A$. myosuroides populations elsewhere in the world (Heap, 2019). However, to our knowledge, this is the first report of Pro197Thr and Trp574Leu in ALS-resistant $A$. myosuroides in Poland. This suggests the increasing resistance of $A$. myosuroides populations in Poland to ALS-inhibiting herbicides. A similar situation has been observed in numerous countries worldwide (Heap, 2019).

The resistance level expressed by decreased biomass accumulation after herbicide treatment was connected with a number of specimens showing a mutation in the als gene as well as with the number of mutations in a specimen. The lowest biomass accumulation decrease was noted in RIII population (Fig. 2). Simultaneously, the largest number of plants with two mutations in the als gene was found among survivors in RIII population (Table 2). A similar relationship has been identified by Deng et al. (2017) in Descurainia sophia biotypes resistant to ALS inhibitor-type herbicides. The RII population showed the greatest reduction of biomass accumulation in the herbicide-treated samples. Here 50\% of the analysed seedlings that survived had no mutation in any domain of the als gene.

Mutations in the als gene confer TRS. Based on the survival rate in RI and RII populations after 2LD treatment, it may be inferred that these populations contained seedlings with TSR and NTSR to mesosulfuron + iodosulfuron. Compared with TSR, NTSR is understudied, because its mechanisms involve multiple gene activities (Petit et al., 2010), making research more complicated. Gardin et al. (2015) have studied NTSR in A. myosuroides, but the analysis of differences in transcriptomic herbicide response between resistant and susceptible plants did not allow for an identification of processes directly explaining NTSR. Nevertheless, the fitness of resistant specimens may be significantly affected by mutation type (Vila-Aiub et al., 2009; Delye et al., 2013). Therefore, the present study analysed possible links between morphological traits of A. myosuroides and a resistance trait to mesosulfuron + iodosulfuron.

The present study's results suggest that resistant biotypes are able to reach particular phenological stages, including maturity, faster. This enables seed dispersal before crop plant harvesting, avoiding hybridisation between resistant and susceptible biotypes and achieving

Table 2. Mutations observed in the als gene of Alopecurus myosuroides plants

\begin{tabular}{|c|c|c|c|c|}
\hline Population & Dose of herbicide & Plant & Pro197 & Trp574 \\
\hline \multirow{3}{*}{$\mathrm{S}$} & \multirow{3}{*}{-} & 1 & $\mathrm{CCC}$ & TGG \\
\hline & & 2 & $\mathrm{CCC}$ & TGG \\
\hline & & 3 & $\mathrm{CCC}$ & TGG \\
\hline \multirow{6}{*}{ RI } & \multirow{3}{*}{$1 \mathrm{LD}$} & 1 & $\mathrm{ACC}$ & TTG/TGG \\
\hline & & 2 & $\mathrm{CCC}$ & TGG \\
\hline & & 3 & $\mathrm{CCC}$ & TGG \\
\hline & \multirow{3}{*}{ 2LD } & 1 & $\mathrm{ACC}$ & TGG \\
\hline & & 2 & $\mathrm{ACC}$ & TTG/TGG \\
\hline & & 3 & $\mathrm{ACC}$ & TGG \\
\hline \multirow{6}{*}{ RII } & \multirow{3}{*}{$1 \mathrm{LD}$} & 1 & $\mathrm{ACC} / \mathrm{CCC}$ & TGG \\
\hline & & 2 & $\mathrm{CCC}$ & TGG \\
\hline & & 3 & $\mathrm{CCC}$ & TTG/TGG \\
\hline & \multirow{3}{*}{ 2LD } & 1 & $\mathrm{CCC}$ & TGG \\
\hline & & 2 & $\mathrm{CCC}$ & TTG/TGG \\
\hline & & 3 & $\mathrm{CCC}$ & TGG \\
\hline \multirow{6}{*}{ RIII } & \multirow{3}{*}{$1 \mathrm{LD}$} & 1 & $\mathrm{ACC}$ & TTG/TGG \\
\hline & & 2 & $\mathrm{ACC}$ & TTG/TGG \\
\hline & & 3 & $\mathrm{ACC} / \mathrm{CCC}$ & TGG \\
\hline & \multirow{3}{*}{$2 \mathrm{LD}$} & 1 & $\mathrm{CCC}$ & TTG \\
\hline & & 2 & $\mathrm{ACC}$ & TTG/TGG \\
\hline & & 3 & TCC & TTG/TGG \\
\hline \multirow{6}{*}{ RIV } & \multirow{3}{*}{$1 \mathrm{LD}$} & 1 & $\mathrm{ACC} / \mathrm{CCC}$ & TGG \\
\hline & & 2 & $\mathrm{GCC} / \mathrm{CCC}$ & TGG \\
\hline & & 3 & $\mathrm{CCC}$ & TTG \\
\hline & \multirow{3}{*}{ 2LD } & 1 & $\mathrm{CCC}$ & TTG \\
\hline & & 2 & $\mathrm{ACC} / \mathrm{CCC}$ & TTG/TGG \\
\hline & & 3 & $\mathrm{ACC}$ & TTG/TGG \\
\hline
\end{tabular}

$\mathrm{S}$ - susceptible; $1 \mathrm{LD}-100 \%$ of label dose $\left(2.4 \mathrm{~g} \mathrm{ha}^{-1}\right.$ of iodosulfuron $+12 \mathrm{~g} \mathrm{ha}^{-1}$ of mesosulfuron); $2 \mathrm{LD}-200 \%$ of label dose (4.8 $\mathrm{g} \mathrm{ha}^{-1}$ of iodosulfuron $+24 \mathrm{~g} \mathrm{ha}^{-1}$ of mesosulfuron) 
a higher level of resistance since larger plants reveal lower herbicide vulnerability (Manalil et al., 2011). The more advanced the plant development, the greater the activity of the GST enzyme (Milner et al., 2001), influencing the effectiveness of herbicides applied in the spring. Moreover, larger weed plants with a higher number of tillers compete more effectively with crop plants, including winter wheat. Different tillering ability may result in a wide range of economic harm caused by A. myosuroides, leading to up to 5\% yield loss with 12 or 25 individuals per $\mathrm{m}^{2}$, as reported by Keller et al. (2014) and Domaradzki et al. (2010), respectively.

Previous results concerning differences in fitness between resistant and susceptible populations are not unequivocal. Some authors have reported that resistant biotypes show a lower biomass rate and/or lower seed production (Vila-Aiub et al., 2009), or herbicide resistance not coinciding with the above-mentioned morphological parameters in comparison to herbicide-sensitive populations (Vila-Aiub et al., 2009; Keshtkar et al., 2017). A negative impact of Pro197 and Trp574 mutations in the als gene on plant fitness in A. myosuroides has not yet been confirmed. In contrast, Trp574Leu mutation in Raphanus sativus has resulted in visible fitness reduction in the population with a mutated als gene, showing $22-38 \%$ and $21-47 \%$ lower seed numbers and yield per plant than the susceptible biotype (Vercellino et al., 2018). Up to now it has not been confirmed that ALS inhibitor-resistant biotypes of $A$. myosuroides show a faster biomass increment and phenological development than susceptible biotypes. However, Delye et al. (2013) have observed later germination and a decrease in fatal germination in $A$. myosuroides specimens with Leu1781 mutation conferring resistance to ACCase inhibitors.

It is expected that individuals with delayed germination have more chance to survive in the field than fast germinating ones thanks to a greater probability of escaping pre-sowing cultural practices. In contrast, in ALS-resistant Apera spica-venti showing NTSR, earlier germination and earlier flowering have been found (Babineau et al., 2017). More rapid growth kinetics has also been observed for ACCase inhibitor-resistant Setaria viridis (Wang et al., 2010).

\section{Conclusions}

1. In two of four resistant populations in all survivors after herbicide treatment resistance conferring mutations in the als gene were identified; however, in the remaining two populations there were survivors without such mutations. Therefore, acetolactate synthase (ALS)inhibitor resistance of examined black-grass (Alopecurus myosuroides Huds.) populations is conditioned both by target-site resistence (TSR) and non-target-site resistance (NTSR).

2. Resistance conferring mutations not identified in Poland before were found in the als gene of the mesosulfuron + iodosulfuron resistant populations of A. myosuroides, which indicates the growing problem of A. myosuroides resistance to ALS inhibitors in Poland.

3. Aboveground biomass accumulation and photosynthetic apparatus efficiency did not differ between the $A$. myosuroides populations examined; however, some resistant populations revealed more intensive tillering in comparison to the sensitive population, which may result in earlier development and more successful competition with crop plants.

Received 16092019 Accepted 16032020

\section{References}

1. Adamczewski K., Kierzek R., Matysiak K. 2016. Multiple resistance to acetolactate synthase (ALS)- and acetylcoenzyme A carboxylase (ACCase)-inhibiting herbicides in black-grass (Alopecurus myosuroides Huds.) populations from Poland. Journal of Plant Protection Research, 56 (4): 402-410. https://doi.org/10.1515/jppr-2016-0059

2. Auškalnienè O., Kadžienė G., Janusauškaitė D., Supronienè S. 2018. Changes in weed seed bank and flora as affected by soil tillage systems. ZemdirbysteAgriculture, 105 (3): 221-226. https://doi.org/10.13080/z-a.2018.105.028

3. Babineau M., Mathiassen S. K., Kristensen M., Kudsk P. 2017. Fitness of ALS-inhibitors herbicide resistant population of loose silky bentgrass (Apera spica-venti). Frontiers in Plant Science, 8: 1660. https://doi.org/10.3389/fpls.2017.01660

4. Darmency H., Menchari Y., Le Corre V., Delye C. 2014. Fitness cost due to herbicide resistance may trigger genetic background evolution. Evolution, 69: 271-278. https://doi.org/10.1111/evo.12531

5. Delye C., Michel S., Berard A., Chauvel B., Brunel D., Guillemin J-P., Dessaint F., Le Corre V. 2010. Geographical variation in resistance to acetyl-coenzyme A carboxylaseinhibiting herbicides across the range of the arable weed Alopecurus myosuroides (black-grass). New Phytologist, 186: $1005-1017$ https://doi.org/10.1111/j.1469-8137.2010.03233.x

6. Delye C., Menchari Y., Michal S., Cadet E., Le Corre V. 2013. A new insight into arable weed adaptive evolution: mutations endowing herbicide resistance also affect germination dynamics and seedling emergence. Annals of Botany, 111: 681-691. https://doi.org/10.1093/aob/mct018

7. Deng W., Yang Q., Zhang Y., Jiao H., MeiY.,LiX., Zheng M. 2017. Cross-resistance patterns to acetolactate synthase (ALS)-inhibiting herbicides of flixweed (Descurainia sophia L.) conferred by different combinations of ALS isozymes with a Pro-197-Thr mutation or a novel Trp-574Leu mutation. Pesticide Biochemistry and Physiology, 136: $41-45$. https://doi.org/10.1016/j.pestbp.2016.08.006

8. Domaradzki K., Rola H. 2006. The harmfulness and possibilities of Alopecurus myosuroides control in the Opole Silesia conditions. Progress in Plant Protection, 46 (1): 232-239.

9. Domaradzki K., Jezierska-Domaradzka A., MarczewskaKolasa K. 2010. Some aspects of biology and harmfulness of Alopecurus myosuroides Huds. Fragmenta Agronomica, 27 (2): 60-69 (in Polish).

10. Doyle J. J., Doyle J. L. 1987. A rapid DNA isolation procedure for small quantities of fresh leaf tissue. Phytochemistry, 19: 11-15.

11. EPPO standard PP 1/181(4). 2012. Conduct and reporting of efficacy evaluation trials, including good experimental practice. Bulletin OEPP/EPPO Bulletin, 42 (3): 382-393. https://doi.org/10.1111/epp.2611

12. Gardin J. A. C., Gouzy J., Carrere S., Delye C. 2015 ALOMYbase, a resource to investigate non-target-sitebased resistance to herbicides inhibiting acetolactatesynthase (ALS) in the major grass weed Alopecurus myosuroides (black-grass). BMC Genomics, 16: 590. https://doi.org/10.1186/s12864-015-1804-x

13. Heap I. 2019. International survey of herbicide resistant weeds. http://www.weedscience.org/

14. Hull R., Tatnell L. V., Cook S. K., Beffa R., Moss S. R. 2014. Current status of herbicide-resistant weeds in the UK. Aspects of Applied Biology, 127: 261-272.

15. Kaiser Y. I., Menegat A., Gerhards R. 2013. Chlorophyll fluorescence imaging: a new method for rapid detection of herbicide resistance in Alopecurus myosuroides. Weed Research, 53: 399-406.

https://doi.org/10.1111/wre.12043

16. Keller M., Gutjahr C., Mohring J., Weis M., Sokefeld M., Gerhards R. 2014. Estimating economic thresholds forsitespecific weed control using manual weedcounts and sensor technology: an example based on three winter wheat trials. Pest Management Science, 70: 200-211. https://doi.org/10.1002/ps.3545 
17. Keshtkar E., Mathiassen S. K., Kudsk P. 2017. No vegetative and fecundity fitness cost associated with acetylcoenzyme A carboxylase non-target-site resistance in a black-grass (Alopecurus myosuroides Huds.) population. Frontiers in Plant Science, 8: 2011. https://doi.org/10.3389/fpls.2017.02011

18. Krysiak M., Gawroński S.W., Kierzek R., Adamczewski K. 2011. Molecular basis of blackgrass (Alopecurus myosuroides Huds.) resistance to sulfonylurea herbicides. Journal of Plant Protection Research, 51 (2): 130-133. https://doi.org/10.2478/v10045-011-0022-z

19. Manalil S., Busi R., Renton M., Powles S. B. 2011. Rapid evolution of herbicide resistance by low herbicide dosages. Weed Science, 59: 210-217. https://doi.org/10.1614/WS-D-10-00111.1

20. Maréchal P.-Y., Henriet F., Vancutsem F., Bodson B. 2012. Ecological review of black-grass (Alopecurus myosuroides Huds.) propagation abilities in relationship with herbicide resistance. Biotechnology, Agronomy, Society and Environment, 16 (1): 103-113.

21. Milner L. J., Reade J.P.H., Cobb A. H. 2001. Developmental changes in glutathione S-transferase activity in herbicideresistant populations of Alopecurus myosuroides Huds (blackgrass) in the field. Pest Management Science, 57 (12): 1100-1106. https://doi.org/10.1002/ps.403

22. Moss S. R., Marshall R., Hull R., Alarcon-Reverte R. 2011. Current status of herbicide-resistant weeds in the United Kingdom. Aspects of Applied Biology, 106: 1-10.

23. Pacanoski Z. 2018. Efficacy of PRE-EM herbicides in grass weed control in winter wheat (Triticum aestivum L.). Acta Herbologica, 27 (1): 21-33. https://doi.org/10.5937/ActaHerb1801021P

24. Petit C., Duhieu B., Boucansaud K., Delye C. 2010 Complex genetic control of non-target-site-based resistance to herbicides inhibiting acetyl-coenzyme A carboxylase and acetolactate-synthase in Alopecurus myosuroides Huds. Plant Science, 178 (6): 501-509. https://doi.org/10.1016/i.plantsci.2010.03.007

25. Powles S. B., Yu Q. 2010. Evolution in action: plants resistant to herbicides. Annual Review Plant Biology, 61 317-347.

https://oi.org/10.1146/annurev-arplant-042809-112119
26. Rosenhauer M., Jaser B., Felsenstein F., Petersen J. 2013. Development of target-site resistance (TSR) in Alopecurus myosuroides in Germany between 2004-2012. Journal of Plant Diseases and Protection, 120 (4): 179-187. https://doi.org/10.1007/BF03356472

27. Trzcińska-Tacik H., Stachurska-Swakoń A. 2011. Alopecurus myosuroides (Poaceae) as the permanent segetal weed of the Skała vicinity in the KrakowCzestochowa Upland. Fragmenta Floristica et Geobotanica Polonica, 18 (2): 221-229 (in Polish).

28. Velička R., Pupalienè R., Butkevičienè L. M., Kosteckas R., Kriaučiūnienè Z., Kosteckienè S. 2018. Weed density in the spring rape crops sown at different dates. ZemdirbysteAgriculture, 105 (1): 21-26. https://doi.org/10.13080/z-a.2018.105.003

29. Vercellino R. B., Pandolfo C. E. Breccia G., Cantamutto M., Presotto A. 2018. AHAS Trp574Leu substitution in Raphanus sativus L.: screening, enzyme activity and fitness cost. Pest Management Science, 74: 1600-1607. https://doi.org/10.1002/ps.4849

30. Vila-Aiub M. M., Neve P., Powles S. B. 2009. Fitness costs associated with evolved herbicide resistance alleles in plants. New Phytologist, 184: 751-767. https://doi.org/10.1111/j.1469-8137.2009.03055.x

31. Wang T., Picard J. C., Tian X., Darmency H. 2010. A herbicide-resistant ACCase 1781 Setaria mutant shows higher fitness than wild type. Heredity, 105: 394-400. https://doi.org/10.1038/hdy.2009.183

32. Yu Q., Powles S. B. 2014 (a). Metabolism-based herbicide resistance and cross-resistance in crop weeds: a threat to herbicide sustainability and global crop production. Plant Physiology, 166: 1106-1118. https://doi.org/10.1104/pp.114.242750

33. Yu Q., Powles S. B. 2014 (b). Resistance to AHAS inhibitor herbicides: current understanding. Pest Management Science, 70: 1340-1350. https://doi.org/10.1002/ps. 3710

34. Zajac M., Zajac A. 2014. Survival problems of archaeophytes in the Polish flora. Biodivesity Research and Conservation, 35: 47-56. https://doi.org/10.2478/biorc-2014-0015

ISSN 1392-3196 / e-ISSN 2335-8947

Zemdirbyste-Agriculture, vol. 107, No. 3 (2020), p. 249-254

DOI 10.13080/z-a.2020.107.032

\title{
Alopecurus myosuroides populiacijų padidèjęs atsparumas sulfonilurèjos grupės herbicidams Šiaurès Rytų Lenkijoje
}

\author{
M. Stankiewicz-Kosyl, M. Wrochna, M. Tołłoczko \\ Varšuvos gyvybės mokslų universiteto \\ Sodininkystès, biotechnologijų ir kraštovaizdžio architektūros fakultetas, Lenkija
}

\section{Santrauka}

Europoje žieminių javų pasėliuose daugèja herbicidams atsparių pelinio pašiaušèlio (Alopecurus myosuroides Huds.) populiacijų, o tai kelia problemų žieminių javų augintojams. Tyrimo tikslas - įvertinti pelinio pašiaušèlio penkiu populiaciju, iš kuriu keturios gali būti atsparios herbicidams ir viena jautri mezosulfuro + jodosulfurono herbicidui (acetolaktato sintezès (ALS) inhibitoriui). Taip pat buvo tirtos als geno mutacijos A bei B srityse ir ryšys tarp atsparumo mezosulfuronui + jodosulfuronui ir augalų išsivystymo ankstyvuoju vegetacijos tarpsniu. Augalų išsivystymas buvo ịvertintas pagal jų krūmijimąsi, vidutinị lapų skaičių, sausos masės kaupimą, chlorofilo kiekị ir II fotosintezès efektyvumą.

Viso augalo tyrimas patvirtino keturių A. myosuroides populiacijų atsparumą ALS inhibitoriams, o biomasès kaupimosi sumažèjimas po herbicido panaudojimo atitiko als atsparumą suteikiančiu genų mutaciju skaičių. Herbicidais neapdorotos populiacijos reikšmingai nesiskyrè nei sukauptos biomasès ir chlorofilo kiekiais, nei II fotosintezès efektyvumu. Tačiau tam tikri ALS atsparūs biotipai krūmijosi intensyviau nei jautrūs biotipai. Tirtose A. myosuroides populiacijose buvo nustatytos atsparumą suteikiančio als geno mutacijos (Pro197Thr ir Trp574Leu), kurios Lenkijoje anksčiau nebuvo nustatytos. Dviejose populiacijose buvo keletas po apdorojimo mezosulfuronu + jodosulfuronu išgyvenusių augalų, kuriems nebuvo nustatyta als geno mutacija. Sių populiaciju išgyvenimo lygis po apdorojimo herbicidais rodo, kad jas sudarè individai, turintys tikslini vietos ir netikslini atsparumo mezosulfuronui + jodosulfuronui pobūdị.

Reikšminiai žodžiai: ALS inhibitoriai, augalų stiprumas, mezosulfuronas + jodosulfuronas, pelinis pašiaušèlis, tikslinis vietos atsparumas. 